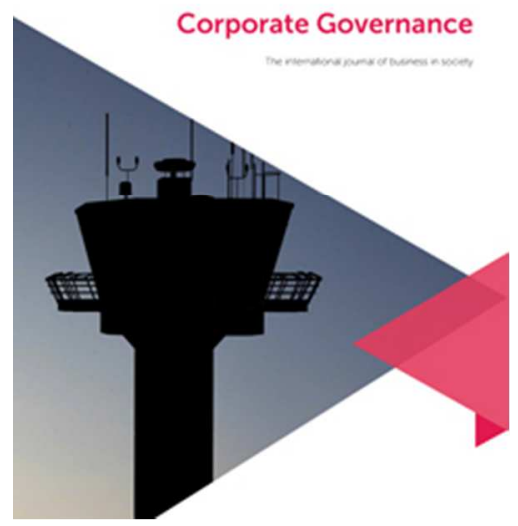

Hide-and-Seek in Corporate Disclosure: Evidence from Negative Corporate Incidents

\begin{tabular}{|r|l|}
\hline Journal: & Corporate Governance \\
\hline Manuscript ID & CG-05-2018-0164.R2 \\
\hline Manuscript Type: & Original Article \\
\hline Keywords: & $\begin{array}{l}\text { legitimacy tactics, corporate disclosure, Corporate Governance, corporate } \\
\text { scandals }\end{array}$ \\
\hline
\end{tabular}




\section{Hide-and-Seek in Corporate Disclosure: Evidence from Negative Corporate Incidents}

Purpose: This paper scrutinizes the legitimacy tactics employed in the annual reports of UK listed companies after their major corporate scandals.

Design/methodology/approach: For a sample consisted of 19 companies that are indulged in corporate scandals, the content analysis approach was used to comprehend how corporate disclosure is used as an intermediary to rationalize corporate actions subsequent to corporate scandals.

Findings: The findings reveal that firms use a wide range of legitimisation strategies in the manner that contribute to shape disclosure communications concerning negative incidents. We discovered that disclosure blur is used by the firms in times when there is an urge intended to create management by the firms for its stakeholders. For instance, some firms may offset the negativity linked to an incident by rendering such explanations amidst positive information.

Originality/value: Contrary to earlier studies conducted on accounting scandals, we incorporated extensive corporate scandals such as human rights violations, controversies pertinent to child labour, environmental scandals, corruption, financial embezzlement, and tax evasion.

\section{Introduction}

This study investigates the legitimisation strategies used by companies during disclosure of negative information in their annual reports. Many studies have focussed on compliance of firms with codes of corporate governance (hereafter ' $\mathrm{CG}$ ') practices (e.g. see Albu and Gîrbină, 2015; Nerantzidis and Tsamis, 2017; Lepore et al., 2018), as opposed to the quality or type of disclosures made by such firms. Thus, our study contributes to the disclosure research within CG literature. Accordingly, companies in several parts of the world are increasingly confronted with countess regulations and $\mathrm{CG}$ practices that obligate managers to declare disclosures regarding various activities of the firm. Accordingly, managers find themselves bewildered either to disclose certain information or retain it and at sometimes end up paying lip service to protect firm's reputation (Laufer, 2006).

Accordingly, such situations may occur where firms are deliberately engaged in unethical activities which may lead to severe consequences if unearthed, such as, annulment of operating licence, or imprisonment of managers. In some cases, firms may unintentionally commit acts that inflict adverse effects on its reputation and for its surrounding (Hahn, 2012). As an instance, BP suffered an accidental oil spill in 2010 which caused a large scale havoc 
in the Gulf of Mexico (Lin-Hi and Blumberg, 2011). This caused damage to the ecosystem in the Gulf of Mexico, with an estimated 5000 barrels of oil spillage per day. Subsequently, the BP acknowledged the huge impact of this tragic event and undertook the responsibility to extricate the spillage. In addition to costly litigation, BP's share prices plummeted due to the devastating environmental disaster (BBC, 2010; Lin-Hi and Blumberg, 2011). This is an instance of how such mishaps can cost a fortune to firms. On the other hand, Volkswagen had forged emissions testing for its vehicles by camouflaging them for low emission vehicles with the intention to attract multitude of customers. This was a deliberate action which resulted in severe erosion of the firm's credibility by its stakeholders as well as lawsuits were instigated by its consumers and environmental campaigners. Other poor practices perpetrated by firms included tax avoidance and labour exploitation (for e.g. Dowling, 2014 and Lewis et al., 2015). According to Hahn (2012) when such catch the attention of firms' stakeholders, the affected firms often respond by denying them, or covering their acts to minimise reputational damage, or admit the guilt with a pledge not to repeat it again.

In addition to internal whistleblowing, country-level institutional factors and the media continue to play a key role in exposing negative incidents and scandals affecting firms globally (Petra, 2006; Adams et al., 2018; Ullah et al., 2018). Such exposures often incite regulatory scrutiny and public reactions resulting in abstention of firm's products or service by customers (Dash, 2012). To overcome such risks, firms adopt various strategies to protect and/or repair their corporate reputation. Extant evidence suggests that firms use various legitimisation strategies to neutralise the consequences of a negative incidents or scandals which threaten their survival (Pollach, 2015; Li et al., 2016). In this paper, we analysed the strategies adopted by firms to dispel negative publicity corporate reputation followed by negative incidents and scandals. We performed content analysis of annual report disclosures provided by UK-based Multinational Enterprises (MNEs) that exhibit the common themes and strategies embraced by firms to rationalise incidents arising from accounting, social and environmental issues. By doing so, we unveiled strategies used by the firms to sustain legitimacy in the aftermath of big scandals and other negative incidents. This study elucidates insights into the responsive strategies adopted by firms for each category of incidents faced by individual firms, i.e. accounting, social and/or environmental issues. As this paper discovers, plenty firms provide voluntary disclosures concerning incidents which affect them (see also Elmagrhi et al., 2016). We also observed that most firms provide disclosures of such corporate incidents within their corporate social responsibility (hereafter 'CSR') 
statements. Consistent with Martínez-Ferrero et al. (2016), we argue that the choice of CSR statements for disclosing corporate incidents is intended to boost stakeholder confidence in the affected firms as well as to safeguard firm reputation within the capital market.

Finally, the findings obtained in this study contribute to literature by providing evidence concerning responses of UK-based MNEs to negative incidents. The paper espouses the approach used by Hahn and Lulfs (2014) in examining corporate disclosure strategies selected by US-based firms to legitimise negative events incidents.

The organizational pattern of this paper follows a section that include discussion of literature review and theoretical framework underpinning this study, a further section that explicates research methodology, the section last section that elaborates the findings obtained in this paper and the last section discusses conclusion.

\section{Literature review and hypothesis development}

\subsection{The Media and Political Costs}

Electronic and print media reports play a significant role in reducing information asymmetry through sharing information with stakeholders (Dash, 2012). The media can influence the information disclosed within firms' annual reports. Firms thus include information within their annual reports to rebut or express regret for claims made by the media. Stakeholders and consumers would be averse to such negative media exposure. Han and Wang (1998) argue that firms tend to provide certain disclosures in order to minimise political costs. This ensures that firms are not exposed to any scrutiny or scandals. Lemon and Cahan (1997) examined the disclosure patterns of the firms operating in environmentally sensitive industries and found that such firms attracted more political attention than others, and also experienced political costs. The studies of Lemon and Cahan (1997) and Han and Wang (1998) subsequently concluded that political attention is correlated with increase in environmental disclosures. Also, Belkaoui and Karpik (1989) found that socially responsible companies show a positive social performance and are likely to disclose positive information in their annual reports. These two studies show that companies are more likely to disclose information if they are under pressure from the society or regulations. Moreover, firms are likely to include sensitive information to assure their stakeholders that they consider environment and their community under consideration and are conscious of future sustainability. 
Literature suggests that companies are more likely to disclose positive information in which they demonstrate responsibility and have a positive public image in the eyes of the stakeholders (Elmagrhi et al., 2016; Lepore et al., 2018). Other empirical evidence shows that different social voluntary disclosure and value-added statements will be used in annual reports in order to reduce the information asymmetry between stakeholders and the companies' management and to create a positive image for the companies (Ness and Mirza, 1991; Panchapakesan and McKinnon, 1992; Deegan and Hallam, 1991; Lim and McKinnon, 1993 and Deegan and Carroll, 1993). Even though the results for these empirical researches show a nexus between social responsibility and the amount of social disclosure in the annual reports, yet they identify that there is no necessary reason why the amount of disclosure should be related to the level of social spending (Milne, 2002). Notwithstanding, firms voluntarily provide information particularly where they deem their actions to be socially and environmentally acceptable (Watts and Zimmerman, 1978).

\subsection{Disclosure Blur}

Chauvey et al. (2015) observed that the amount of disclosures provided within annual reports of firms continues to increase over time. This includes a variety of information concerning social and environmental factors related to firms. However, the writers questioned the utility of such information. They argue that its quality is poor owing to factors such as vague information often provided to conceal negative incidents or scandals and protect the firm's legitimacy (Laufer, 2006; Chauvey et al., 2015). Nevertheless, a company's legitimacy may be threatened after disclosure of negative incidents and events, and managers must therefore choose whether to disclose such information or to hide it from public. According to Bansal and Clelland (2004), companies disclosing negative information about themselves jeopardize their legitimacy particularly if the reported incidents contravenes society's expectations.

On the other hand, companies that fail to disclose negative incidents and scandals affecting them to stakeholders also risk losing their legitimacy often with negative repercussions in the event that information is revealed by the media or whistle-blowers (Heide and Våland, 2005; Dash, 2012; Reimsbach and Hahn, 2015). In light of these observations, the disclosure of negative scandals is a critical and sensitive issue and ought to be handled with due care by the firms (Janssen et al., 2015). Disclosure of negative information as well as failure to do so have the potential to tarnish a company's legitimacy (Bitektine and Haack, 2015). Lundholm and Van Winkle (2006) argued that it is not the case whether the information will be revealed rather when it will be revealed. These writers further observed that although negative 
incidents can cause conflicts between a company and society, yet the way such information is disclosed possess the potential to discard or control the impact of negative information. Not the least, Janney and Gove (2011) argued that any negative information emanating from third parties may suggest that the affected company is trying to hide some information from the public and thus risking severe damage to its legitimacy.

Companies that have encountered negative incidents can still improve their image by disclosing the strategies they are using or intending to use so that the problem can be remedied (Hooghiemstra, 2000; Adams and Zutshi, 2004). This is also vital in ensuring that stakeholders' perceptions are corrected (Hooghiemstra, 2000; Cormier and Gordon, 2001; Holder-Webb et al, 2009). However, existing evidence suggests that most firms prefer to make disclosures regarding positive issues (Deegan and Rankin, 1996; Milne et al, 2009; Khan et al., 2013). For instance, Deegan and Gordon (1996) observed that various companies disclose little negative information while prefer to disclose abundance of positive information. Instances of the positive disclosure observed within empirical literature include: voluntary adoption of environmental practices (for e.g. Mitra and Datta, 2014 and Zeng, 2012), establishment of wildlife preservation areas (for e.g. see Harris, 2014 and Carruthers, 2012) and energy saving measures (Mata et al., 2013; Pombo et al., 2016 and Nisiforou et al., 2012). Conversely, the negative disclosure observed in the related literature incudes 'admission of causing environmental or health related problems' (De Villiers and Alexander, 2014), and 'pollution and waste management challenges and investigations by authorities' (Cormier and Magnan, 2015 and Matsumura et al., 2013). Nevertheless, Holder-Webb et al. (2009) while examining the disclosures of US firms under government investigation concluded that the disclosure quality is poor as information provided was vague, lacked depth and was less useful to stakeholders. This evidence suggests that some companies may reveal CSR disclosures merely as a way of paying lip service.

The variety of approaches used by companies to restore or protect their legitimacy is well documented in literature. Some companies may deny the incident and shift the blame to the accidents, make claims that their actions are better than other companies or countering the accuser to reduce the accuser's credibility (Suchman, 1995; Benoit, 1997). The present study argues that the effectiveness of such approaches in restoring a company's reputation is likely to vary from approach to approach, company to company, or industry to industry. It is also possible that the type of approach adopted may be informed by the type and severity of the incident at hands. What is evident in literature is that, although various firms disclose both 
positive and negative voluntary information, most disclosures contain mainly positive information (Clatworthy and Jones, 2003).

Literature also shows that many companies prefer to attribute negative news to external factors instead of realizing their internal weaknesses. This observation is consistent with the findings of Yuthas et al. (2002) which suggests that firms with negative news tend to use fewer self-referral terms, such as, 'we' and 'our'. This choice of the language can be interpreted as a strategy to attribute the negative information to externalities instead of the affected company. Some companies have been involved in using persuasive strategies to influence stakeholders' perceptions while reporting negative incidences, including narrating their past successes or associating it with parent company's reputation (Higgins and Walker, 2012). Other companies deem the disclosure of negative information as inconsequential (Hahn and Lülfs, 2014). In this context, companies adopt a series of language styles to manipulate stakeholders' perceptions. This can include, but is not limited to, using vague and ambiguous phrases, numbers and statements (Hahn and Lülfs, 2014).

In this paper, we investigate how UK companies make CSR disclosures particularly by focussing on how explanations regarding negative incidents and scandals are documented within CSR reports.

\subsection{Legitimacy Theory}

Gray et al. (1995) argue that undertaking voluntary disclosures not only enhance corporate transparency but also boost companies' image in the eyes of their stakeholders. Consistent with the legitimacy theory's assumption, stakeholders' attitudes and perceptions about companies are significantly influenced by the information disclosed by each company. However, such disclosures may show how a company is dealing with positive or negative issues affecting it including societal and environmental pressures. Other disclosures may also be an acknowledgement of errors and mistakes that individual companies may have made including the plans how affected companies intend to overcome their mistakes to improve their public image. Accordingly, Suchman (1995) thus suggests that legitimacy is the perception concerning an entity's actions compared with societal norms and values.

Chan et al. (2014) argue that stakeholders and public in general can boycott the products of a company which is deemed to be engaged in illegitimate activities that contravene societal expectations. For this reason, firms are increasingly under pressure to provide disclosures 
about sustainability, societal \& environmental impact of their actions and not merely their financial performance. Such disclosures are intended to earn, maintain, or restore legitimacy and demonstrate social responsibility to stakeholders (Dowling and Pfeffer, 1975; Deegan, 2002; O’Donovan, 2002). Notwithstanding, some firms choose to provide extra disclosures than required by the existing regulations. As Branco and Rodrigues (2006) further contend, larger companies tend to attract more CSR scrutiny than smaller companies due to manifold regulations and involvement of several stakeholders. It therefore suggests that larger companies are likely to make more CSR disclosures than the small-sized firms, and their legitimacy in contrast to the smaller firms is in peril (Ashforth and Gibbs, 1990 and Morsing and Shultz, 2006).

To achieve legitimacy, Van Staden and Hooks (2007) argue that companies can use a reactive or proactive approach. The reactive approach occurs where companies provide explanations related to a recent event, crisis or scandal within their CSR statements. On the other hand, a proactive approach involves companies providing continuous disclosures about their activities and risks, both current and anticipated, as a way of protecting their legitimacy (Neu et al., 1998; Arvidsson, 2010; Nerantzidis and Tsamis, 2017). Companies may also provide CSR disclosures with an intention to manipulate stakeholders' perceptions as opposed to merely being transparent. In addition, evidence suggests that some disclosures regarding corporate social and environmental performance could sometimes be ambiguous or inadequate (Archel et al., 2009).

\section{Methodology}

The sample of this study is composed of nineteen companies which are associated with the United Kingdom either through the sale of products or owe subsidiaries that operate in the United Kingdom. The data collection involved collecting generic and specific keywords from the firms' annual reports (i.e. CG statements and CSR reports). The collected date was then sorted into one of eight legitimisation strategies, i.e.: (i) marginalisation, (ii) abstraction, (iii) indicating facts, (iv) institutional rationalisation, (v) theoretical rationalisation, (vi) authorisation, (vii) corrective action type 1 and (viii) corrective action type 2 . Table 1 presents the definitions of these categories.

[Insert table 1 here] 
We utilised an interpretivist philosophical standpoint in addressing the research problem pursued in the present study (see e.g. Othman and Rahman 2014; Atkins and Maroun 2015; Nakpodia et al. 2016). This method of inquiry permitted authors to carry out content analysis of annual report information with a view to identify legitimisation strategies used by companies following occurrence of negative incidents or scandals. Moreover, an interpretivist stance was favoured owing to its flexibility (Stake, 2005; Saunders, 2015), allowing authors to use judgement in identifying and constructing common themes about strategies used by firms to explain the occurrence of accounting, environmental and social issues. After reading the information contained in each annual report, i.e., CG statement and CSR report, the authors utilised inductive approach to discern similarities in disclosure statements intended to repair firm reputation and legitimacy.

Content analysis was carried out by searching keywords related to negative incidents or scandals followed by categorization of each such statements. Examples of keywords identified included: "incident”, “accident”, “harm”, “risk”, “conflict”, “negative”, "human rights", “environment", "scandal”, “corruption”, "bribery”, “tax avoidance”, “child labour”, and "discrimination". Similar keywords were merged to create common themes. Each incident or scandal (captured by the keywords) were juxtaposed with the legitimisation strategy published in the annual report explanation (See Table 2 for a full list of keywords used).

[Insert table 2 here]

The qualitative content analysis employed in this study followed the procedure recommended by Bos and Tarnai (1999). The first step commenced at a theoretical level where the research problem and research questions were identified upon reviewing literature. The next step involved establishment of the 'study sample' and 'unit of analysis', In the subsequence step, the themes identified to determine the validity and reliability of the data and the potential findings were pretested. The last procedure involved interpretation of results.

Content analysis can also lead to some challenges that have been considered in this study. Steenkamp and Northcott (2007) and Graneheim et al. (2017) identified some challenges that need to be addressed. First, the choice of unit of analysis; the difficulty to determine where to analyse a sentence or a paragraph. The paragraph gives the reader an accurate context and interpretation of the voluntary disclosure. However, due to the nature of this study, it would be more beneficial to analyse sentences. The reason being that the keywords would need to 
be identified in order to capture the addressing of the problem and the strategy used to repair their legitimacy. Another challenge can be the repetition of units- the use of the same keywords, phrases or themes. This creates difficulty as to how many times the same keywords or phrases are used throughout the text. This would be treated accordingly with the analysis of sentences; each sentence would be a different unit to analyse. Therefore, each repetitive message should be treated as a new piece of data. Holsti (1969) also identified that the use of repetitive text depends on the size of the context unit. However, it is still acknowledged that it is difficult to judge whether repetition should be included if they are in close proximity to each other (See e.g. Song et al. 2018). Steenkamp and Northcott (2007) identify substantive judgements as a practical challenge when using content analysis. Krippendorff (2004) and Stanton and Stanton (2002) expounds that while using content analysis, the text isn't confined to a single meaning rather it is further owed to the reader's judgement. Therefore, the interpretation of the text become strenuous to determine. Other possible meanings should be considered when analysing each disclosure on the grounds that every reader would not interpret each sentence in similar way.

The data was collected from annual report information released by each individual company considered in this study. This enabled the authors to understand how various companies acknowledge incidents and scandals that affect them. We were also able to perceive how companies make voluntary disclosures including intents of legitimising strategies. The legitimising strategies have been studied following the approach utilised in earlier studies (for e.g. see Hahn and Lulfs, 2014; Talbot and Boiral, 2015; Castelló et al., 2016; and Hyndman and Liguori, 2016).

The analysed companies have been selected for analysis on the basis of the scandals or incident that fitted well into one of the three categories: social, environmental or accounting. Furthermore, only those companies were selected for analysis that had experienced negative or scandalous incidents. The operations of the companies must also have been based in the UK; selling their products; subsidiary or their head office. These companies were also selected on the rationale regarding the nature of the incident or the scandal as well as the year in which the incident incurred (See Table 3).

[Insert table 3 here]

A summary of the key findings is presented in the results section. 


\section{Results}

This section provides a detailed discussion of the results acquired in this study. The analysis of the data resulted in the identification of seven common themes associated with the legitimisation strategies adopted by the UK firms during the provision of disclosures linked to negative incidents and scandals affecting them. Table 4 illustrates an overview of the coding scheme regarding how different explanations in response to corporate scandals were coded using reported text from the corporate documents (annual reports).

[Insert table 4 here]

Table 4 depicts a summary of legitimation strategies used for the different categories of scandals. As evident from the descriptive analysis, non-compliant companies have employed a profusion of justifications and plenitude of legitimation strategies that include stipulated facts and assurance of taking remedial measures against non-compliance.

[Insert table 5 here]

In terms of reliability of the coding scheme, we asked two coders to independently code five relevant annual reports using our categorisation scheme. We then compared the degree of agreements between the two coders using the Cohen's Kappa test of agreement. The purpose of this test is to determine whether independent coders will also code a category of explanation (disclosure) in similar manner as coded by the researchers (Krippendorff 2004). The Cohen Kappa test yielded a similarity statistic of $72 \%$ which confirms the validity of our coding scheme.

In the following sub sections, we have provided a critical account of the tactics used in the corporate disclosure.

\subsection{Marginalisation}

This legitimisation strategy is used where companies intend to declare an incident as 'insignificant', or less detrimental to itself and others as 'affected' (Talbot and Boiral 2015). For instance, one company provided the following explanation in the backwash of an incident: "While no significant community incidents occurred at our operated sites, we deeply regret the significant community impacts of the dam failure at our non-operated joint venture, Samarco" (BHP Billiton, 2016: 37). Such explanation illustrates an attempted legitimisation strategy where the company attempts to downplay the incident in question. In addition, only the description of the incident is provided in the disclosure statement. By doing 
so, affected companies deliberately choose not to mention the nature of their operations within the disclosure narrative. This way, companies isolate the disclosed incidents from their own operations in an endeavour to portray the incident as negligible. However, such treatment of negative incidents as peripheral issues can affect the ability of stakeholders to make effective decisions and judgement regarding the matter at hand; that is, negative incidents and scandals affecting a company. Conversely, one may argue that a company's managers would have extracted time to assess the impact of every incident on the firm's operations before making any disclosures (Idowu et al. 2017). Nevertheless, stakeholders are denied an opportunity to carry out their own evaluation of incidents associated with a company particularly so when companies provide little explanation about an incident or how it affects the operations of a firm.

\subsection{Abstraction}

The data analysed also show that firms employ an abstraction strategy to legitimise negative incidents. This strategy is found where companies generalise a negative incident to demonstrate as if an incident has affected many companies besides the company in question (Castelló et al. 2016). Such explanations also tend to be very equivocal in nature. An example of such disclosure is illustrated in the following statement:

"Many transactions that occur during the ordinary course of business for which the ultimate tax determination is uncertain” (Amazon, 2014:21).

This example shows obscure phrases and vocabulary such as 'many transactions' and 'ordinary course of businesses. This suggests that the incident could have occurred to any company. Another disclosure statement analysed for the purposes of this study read as below: "The healthcare sector is highly competitive and subject to regulation. This increases the instances where we are exposed to activities and interactions with bribery and corruption risk." (GSK, 2014: 43).

Our analysis ascertains that companies may attempt to provide disclosure statements generalised to the wider industry or the sector in which the company operates so as to depict an incident as a collective problem rather than company specific. Companies may particularly attempt to do so if they are unable to solve a problem, or where managers want to shift blame from themselves to other external factors by portraying it as industry challenge. This legitimacy tactic (abstraction) is intended to make stakeholders believe that the problem didn't emerge due to the company's performance (e.g. see Ayertey and Asrat, 2017) 


\subsection{Indicating Facts}

This legitimising strategy involves a company to simply disclose a negative incident which has occurred without going into details to provide an evaluation of how the incident impacts its activities (Talbot and Boiral 2015). Examples of such disclosure statements include: "The tragic accident in the Gulf of Mexico on 20 April 2010 cost 11 lives, leading to a major oil spill and a widespread loss of trust in BP" (BP, 2010: 2). Such statements may even involve measurement of some aspects of the incident but fail to provide detailed explanation or account to stakeholders about costs or causes of the incident. The following statement is another example illustrating how companies disclose negative incidents, in line with "indicating facts" strategy:

"The fire burned for 36 hours before the rig sank, and hydrocarbons leaked into the Gulf of Mexico for 87 days before the well was closed and sealed" (BP, 2010: 7).

The problem with this disclosure approach is that it doesn't allow stakeholders to comprehend the implications of disclosed incidents on firm performance or reputation. Such indicating facts may require comparison with past incidents or predefined benchmarks in order to understand their impact on firm activities and legitimacy. Thus, companies may employ the use of enumeration to protect their legitimacy. The less keen stakeholders may perceive such disclosures as an unbiased and accurate description of incidents without realising that they lack vital details necessary to interpret the figures provided.

\subsection{Rationalisation}

Instrumental rationalisation provides justification after occurrence of a negative incident. This strategy involves companies highlighting benefits accrued at the same time an incident occurred (Hyndman and Liguori, 2016). Companies utilising the rationalisation strategy in making negative disclosures have been observed to use terms such as 'due to' or 'caused by' in an attempt to neutralise the adverse news and portray the company favourably (Hahn and Lülfs, 2014). In addition, companies may employ a theoretical rationalisation strategy whereby negative incidents are justified by portraying them as standard behaviour. As an instance, our analysis divulged the following use of theoretical rationalisation in some companies' disclosure statements:

"We are exposed to bribery and corruption risk through our global business operations." (GSK, 2014: 43); and, "We are subject to income taxes in the U.S. (federal and state) and 
numerous foreign jurisdictions. Tax laws, regulations, and administrative practices in various jurisdictions may be subject to significant change due to economic, political, and other conditions, and significant judgment is required in evaluating and estimating our provision and accruals for these taxes" (Amazon, 2014: 20).

Such statements, as our analysis reveal, are intended to make stakeholders believe that the reported incidents are inevitable during the company's operations. In the case of two earlier cited examples, the disclosure statements appear to suggest that the companies are particularly susceptible to negative incidents due to their large operations diffusion across the globe. This legitimisation strategy implies that the companies have no mechanism to counter the risk of these negative incidents and is left to deal with them as they erupt.

\subsection{Authorisation}

This legitimisation strategy uses the names of governing bodies or authority when detailing, explaining or justifying a negative incident. It can also include citing an individual in a position of authority within or outside the company such as the CEO, director of the company, or officials of regulatory bodies (Hahn and Lülfs, 2014). An example of a disclosure statement employing authorisation strategy to safeguard its legitimacy, includes: "We partnered with Conservation International, a global environmental non-profit organisation, to develop Responsible Sourcing Guidelines (RSGs)" (Nestlé, 2012: 129). This disclosure statement shows that the company 'Nestle' has been proactively working together with a leading environmental conservation body to resolve a negative environmental incident. Such statement also gives credence to Nestle's environmental practices. Our analysis finds that the decision of a company to associate itself with an authoritative/respected organisation in articulating news about a negative incident or scandal helps to safeguards its legitimacy. This may also include disclosures of a company's collaboration with a respected third-party in finding a solution to the incident.

\subsection{Corrective Action}

Our analysis further found that some firms employ corrective action approach in providing disclosures concerning negative incidents. According to this strategy, firms not only provide details about a negative incident affecting them but move further to explain the steps undertaken to resolve those conundrums. We identified two forms of corrective action strategies utilised by the firms analysed, i.e., corrective action type I, and, corrective action type II. The corrective action type I involves explanation concerning how the disclosed 
incident was resolved or the measures initiated to deter such incidents from occurrence in future. Nevertheless, our analysis finds that some companies disclosure statements include abstruse or generic explanations of procedures taken to repel a negative incident; i.e. "We are committed to continuously enhancing the safety and risk management of our operations and we will continue to do so in the wake of this tragedy" (BHP Billiton, 2016: 5), and, "Final restoration plans will be developed when the injury assessments are complete" (BP, 2010: 12). These statements demonstrate that some measures will be executed to resolve and prevent the future occurrence of the problems cited. However, no precise or detailed procedures that shall be followed has been provided. As an instance, the two disclosure excerpts above failed to explain the actual 'enhancements' or 'restoration plans' respectively that will be implemented. This method of disclosure however provides some legitimacy on part of the company by implying that the company has already taken steps to address the problem. Corrective action type II, on the other hand, is a legitimisation strategy where a disclosure statement indicates the precise steps taken to resolve an incident as well as preventive measures to safeguard similar incidents in future. An example of a corrective action type II is as follows:

"In the 1.6 l TDI engines, a "flow transformer" will be fitted in front of the air mass sensor to improve the sensor's measuring accuracy. Combined with updated software, this will optimize the amount of diesel injected"' (Volkswagen, 2015).

In this example, the company - Volkswagen - clearly outlines the measures that it has developed to rectify the emissions level of its cars fitted with 1.6 1 TDI diesel engines. This includes details of the component to be installed to eliminate the emission problem along with precise location where it will be fitted. This strategy towards disclosure helps stakeholders to understand how a company deals with challenging incidents, and subsequently enhances firm legitimacy.

\section{Discussion of results}

The six legitimation strategies discussed in the preceding section were found to emerge from incidents that fall into three categories: social, environmental and accounting-based issues. Our analysis further found consistency between each category of incident and legitimisation strategy commonly adopted by firms. We found most firms with social incidents to use corrective action type II legitimisation strategy. This legitimisation strategy is also the most 
popular relative to corrective action (type I) (as our results are aligned with the studies; for e.g. Borghei et al. 2016; and Islam et al. 2016). We also found no evidence of firms using other legitimisation strategies when dealing with social incidents besides corrective action approach. This may be interpreted to suggest that the other strategies might lack the same legitimation effect when firms are dealing with social incidents. Companies may also prefer to use corrective action strategy to demonstrate their commitment to stakeholders in resolving social problems caused. However, companies utilising corrective action type I strategy can be argued to provide imprecise and/or undetailed information about incidents affecting them. This may be an elaborate strategy intended to detract attention from an incident and subsequently protecting legitimacy of such firms.

Further, our results show that most firms with negative environmental incidents tend to employ correction action type II legitimising strategy, followed by type I. However, the data examined also showed some disclosure statements which indicating facts and authorisation strategies respectively. Moreover, some disclosure statements pertaining to environmental incidents were found to exhibit more than one legitimisation strategy. We argue that such a multi-faceted approach towards disclosure may be intended to prevent loss of firm legitimacy, particularly where an incident has a potential long-term danger to a firm. In that case, the use of facts indicates an acknowledgement of the incident by the affected firm while association with authorities may endorse the steps taken by a firm. This evidence means that environmental incidents are seriously considered in the UK. Thus, the firms that encounter negative environmental incidents are likely to experience a very high risk of losing their legitimacy. This might explain the diverse legitimisation strategies adopted by firms which encounter environmental incidents.

Finally, our analysis showed that firms with incidents that are accounting in nature prefer to employ corrective action type II and I strategies followed by indicating facts in that order. We attribute this preference of legitimisation strategies to the fact that accounting is a domain that is heavily regulated compared to the other two areas - social and environmental matters. This means that the firms which encounter accounting incidents will want to provide reassurance to their stakeholders and will alleviate any uncertainties concerning firms' relationship with regulators. By doing so, firms also ensure that their annual report information and other communications are taken seriously by their stakeholders. We therefore ague that it is for this reason that the firms are observed to acknowledge accounting incidents and disclose such 
information to stakeholders as well as actions taken or considered to resolve them. This way, firms can regain their legitimacy.

\section{Conclusion, limitations and avenue for future research}

This study enhances our understanding of the legitimisation strategies utilised by the UK firms after the occurrence of negative incidents and scandals which are of social, environmental or accounting nature. This follows from observation that firms are integrating comprehensive CSR statements within their annual reports as a way of shielding corporate legitimacy (Laufer, 2006; Elmagrhi et al., 2016). Many companies also use their CSR reports to address sensitive events and problems which affect them. Negative incidents usually attract negative media coverage and subsequently firms are under immense scrutiny from stakeholders (Dash, 2012). Companies thus always respond to media reports about incidents affecting them. They do this to limit or alleviate damage to their corporate legitimacy. Accordingly, the present study investigated how listed UK firms disclose and/or explain negative incidents affecting them.

Our findings show that firms use a range of legitimisation strategies in the way they build corporate communications concerning negative incidents as well as well the amount of information provided. The study finds that firms use disclosure blur where they provide information that is intended to create impression management on their stakeholders. For instance, some firms may offset the negativity related to an incident by placing such explanations amidst positive information. Following the approach of Hahn and Lülfs (2014), we identified eight legitimisation strategies that have been used by UK firms in disclosing negative information as follows: marginalisation, abstraction, indicating facts, instrumental rationalisation, theoretical rationalisation, authorisation, corrective action type I and corrective action type II.

Following a content analysis technique, our analysis show that seven out of the eight legitimisation strategies hypothesised by Hahn and Lülfs (2014) have been used at least once, apart from instrumental rationalisation. The results show that social incidents involve a high amount of type I and type II corrective actions. Therefore, information on the incident may be vague, however, the companies would provide extensive details on the resolution and future prevention of similar incidents. Many firms also adopt corrective action types I and II in dealing with incidents of environmental nature. Not least, indicating facts and authorisation also appear to be used in moderate frequency in dealing with environmental incidents. We 
conclude that these two additional legitimisation strategies are potentially used to validate firms' post-incident actions through association with external parties. We also find that the category of incident - social, environmental or accounting, matters for the type of legitimisation strategy selected.

The present study utilised a relatively small sample size of nineteen companies. Future comparative studies may consider employing a larger sample size from different corporate governance systems to substantiate whether the findings are robust to different institutions environment. We find no evidence of UK companies using legitimisation strategies such as: 'complete denial or use of positive statements' that veil negative incidents. Future studies may also extend this research in other countries such as those in the European Union, to ascertain whether the legitimisation strategies found in this study also exist in such countries. Another possible avenue for research is to carry out multi-country analysis to determine the extent of similarities or differences in legitimisation strategies used by the firms in various jurisdictions. 


\section{References}

Adams, C. and Zutshi, A. (2004), "Corporate social responsibility: Why business should act responsibly and be accountable", Australian Accounting Review, Vol. 14 No. 34, pp. 31-39.

Adams, D., Ullah, S., Akhtar, P., Adams, K. and Saidi, S. (2018), "The role of country-level institutional factors in escaping the natural resource curse: Insights from Ghana", Resources Policy, In press, corrected proof, Available online 21 March 2018. DOI: https://doi.org/10.1016/j.resourpol.2018.03.005

Albu, C. N. and Gîrbină, M. M. (2015), 'Compliance with corporate governance codes in emerging economies. How do Romanian listed companies “comply-or-explain”?', Corporate Governance: The International Journal of Business in Society, Vol. 15 No. 1, pp. 85-107.

Amazon. (2014), "2014 Annual Report", available at: http://phx.corporateir.net/External.File?item=UGFyZW50SUQ9MjgxMzI2fENoaWxkSUQ9 TF8VHlwZT0z\&t=1 (accessed 19 April 2018).

Archel, P., Husillos, J., Larrinaga, C. and Spence, C. (2009), "Social disclosure, legitimacy theory and the role of the state", Accounting, Auditing \& Accountability Journal, Vol. 22 No. 8, pp. 1284-1307.

Arvidsson, S. (2010), "Communication of corporate social responsibility: A study of the views of management teams in large companies", Journal of Business Ethics, Vol. 96 No. 3, pp. 339-354.

Ashforth, B.E. and Gibbs, B.W. (1990), “The double-edge of organizational legitimation", Organization Science, Vol. 1 No. 2, pp. 177-194.

Atkins, J. and Maroun, W. (2015), "Integrated reporting in South Africa in 2012: Perspectives from South African institutional investors", Meditari Accountancy Research, Vol. 23 No. 2, pp.197-221.

Ayertey, B. and Asrat, G.M. (2017), "Legitimation Strategies in the reporting of Negative CSR Aspects" Unpublished MBA Thesis, Dalarna University. Available at: http://www.divaportal.org/smash/get/diva2:1105652/FULLTEXT01.pdf (accessed 19 April 2018).

Bansal, P. and Clelland, I. (2004), "Talking trash: Legitimacy, impression management, and unsystematic risk in the context of the natural environment", The Academy of Management Journal, Vol. 47 No. 1, pp. 93-103.

BBC. (2010), "BP faces choppy waters after huge oil spill", available at: http://news.bbc.co.uk/1/hi/world/americas/8652448.stm (accessed 19 April 2018).

BBC. (2010), "BP vows to clean up Gulf of Mexico oil slick", available at: http://news.bbc.co.uk/1/hi/world/americas/8658081.stm (accessed 19 April 2018).

BBC. (2010), “Oil 'reaches' US Gulf Coast from spill”, available at: http://news.bbc.co.uk/1/hi/world/americas/8653162.stm (accessed 19 April 2018).

Belkaoui, A. and Karpik, P.G. (1989), "Determinants of the corporate decision to disclose social information”, Accounting, Auditing \& Accountability Journal, Vol. 2 No. 1, pp. 36-51.

Benoit, W.L. (1997), "Image repair discourse and crisis communication", Public Relations Review, Vol. 23 No. 2, pp. 177-186. 
BHP Billiton (2016) "Sustainability Report 2016", available at: http://www.bhp.com//media/bhp/documents/investors/annualreports/2016/bhpbillitonsustaina bilityreport2016.pdf (accessed 19 April 2018).

Bitektine, A. and Haack, P. (2015), "The "macro" and the "micro" of legitimacy: Toward a multilevel theory of the legitimacy process", Academy of Management Review, Vol. 40 No. 1, pp. 49-75.

Borghei, Z., Leung, P. and Guthrie, J. (2016), "The nature of voluntary greenhouse gas disclosure-an explanation of the changing rationale: Australian evidence", Meditari Accountancy Research, Vol. 24 No. 1, pp.111-133.

Bos, W. and Tarnai, C. (1999), "Content analysis in empirical social research", International Journal of Educational Research, Vol. 31 No. 8, pp. 659-671.

BP. (2010), “Sustainability Review 2010”, available at: http://www.bp.com/content/dam/bp/pdf/sustainability/groupreports/bp_sustainability review 2010.pdf (accessed 19 April 2018).

Branco, M.C. and Rodrigues, L.L. (2006), "Communication of corporate social responsibility by Portuguese banks: A legitimacy theory perspective", Corporate Communications, Vol.11 No. 3, pp. 232-248.

Carruthers, J. (2012), "National Parks in South Africa”, in Child et al. ( $1^{\text {st }}$ Ed.) Evolution and Innovation in Wildlife Conservation”, Routledge, London.

Castelló, I., Etter, M. and Årup Nielsen, F. (2016), "Strategies of legitimacy through social media: The networked strategy", Journal of Management Studies, Vol. 53 No. 3, pp.402-432.

Chan, M.C., Watson, J. and Woodliff, D. (2014), "Corporate governance quality and CSR disclosures”, Journal of Business Ethics, Vol. 125 No. 1, pp. 59-73.

Chauvey, J., Giordano-Spring, S., Cho, C.H. and Patten, D.M. (2015), "The Normativity and Legitimacy of CSR Disclosure: Evidence from France", Journal of Business Ethics, Vol. 130 No. 4, pp. 789-803.

Clatworthy, M. and Jones, M.J. (2003), "Financial reporting of good news and bad news: evidence from accounting narratives", Accounting and Business Research, Vol. 33 No. 3, pp. 171-185.

Cormier, D. and Gordon, I.M. (2001), “An examination of social and environmental reporting strategies”, Accounting, Auditing \& Accountability Journal, Vol. 14 No. 5, pp. 587-616.

Cormier, D. and Magnan, M. (2015), “The economic relevance of environmental disclosure and its impact on corporate legitimacy: An empirical investigation", Business Strategy and the Environment, Vol. 24 No. 6, pp.431-450.

Dash, A. K. (2012) "Media impact on corporate governance in India: a research agenda," Corporate Governance: The International Journal of Business in Society, Vol. 12 No. 1, pp.89-100.

De Villiers, C. and Alexander, D. (2014), "The institutionalisation of corporate social responsibility reporting", The British Accounting Review, Vol. 46 No. 2, pp.198-212. 
Deegan, C. and Carroll, G. (1993), "An analysis of incentives for Australian firms to apply for reporting excellence awards", Accounting and Business Research, Vol 23 No.91, pp. 219227.

Deegan, C. and Hallam, A. (1991), "The voluntary presentation of value added statements in Australia: a political cost perspective", Accounting \& Finance, Vol. 31 No. 1, pp. 1-21.

Deegan, C. and Gordon, B. (1996), "A study of the environmental disclosure practices of Australian corporations", Accounting and Business Research, Vol. 26 No. 3, pp. 187-199.

Deegan, C. and Rankin, M. (1996), "Do Australian companies report environmental news objectively? An analysis of environmental disclosures by firms prosecuted successfully by the Environmental Protection Authority", Accounting, Auditing \& Accountability Journal, Vol. 9 No. 2, pp.50-67.

Deegan, C. (2002), "The legitimising effect of social and environmental disclosures - a theoretical foundation", Accounting, Auditing \& Accountability Journal, Vol. 15 No. 3, pp. 82-311.

Dowling, G.R. (2014), "The curious case of corporate tax avoidance: Is it socially irresponsible?” Journal of Business Ethics, Vol. 124 No.1, pp.173-184.

Dowling, J. and Pfeffer, J. (1975), “Organizational Legitimacy: Social Values and Organizational Behavior”, The Pacific Sociological Review, Vol.18 No. 1, pp.122-136.

Elmagrhi, M. H., Ntim, C. G. and Wang, Y. (2016) “Antecedents of voluntary corporate governance disclosure: a post-2007/08 financial crisis evidence from the influential UK Combined Code", Corporate Governance: The International Journal of Business in Society, Vol. 16 No.3, pp.507-538.

Graneheim, U.H., Lindgren, B.M. and Lundman, B. (2017), "Methodological challenges in qualitative content analysis: A discussion paper", Nurse Education Today, Vol. 56 No. 1, pp.29-34.

Gray, R., Kouhy, R. and Lavers, S. (1995), "Corporate social and environmental reporting: A review of the literature and a longitudinal study of UK disclosure", Accounting, Auditing \& Accountability Journal, Vol. 8 No. 2, pp.47-77.

GSK. (2014), "Annual Report 2014", available at: http://www.gsk.com/media/2711/annualreport-2014.pdf (accessed 19 April 2018).

Hahn, R. (2012), "Standardizing social responsibility? New perspectives on guidance documents and management system standards for sustainable development", IEEE Transactions on Engineering Management, Vol. 59 No. 4, pp. 717-727.

Hahn, R. and Lülfs, R. (2014), "Legitimizing negative aspects in GRI-Oriented sustainability reporting: A qualitative analysis of corporate disclosure strategies", Journal of Business Ethics, Vol. 123 No. 3, pp. 401-420.

Han, J. C. Y. and Wang, S. (1998), "Political costs and earnings management of oil companies during the 1990 Persian Gulf crisis", The Accounting Review, Vol. 73 No. 1, pp.103-117.

Harris, J. (2014), Wildlife conservation in China: preserving the habitat of China's Wild West, 1 st ed., Routledge, New York. 
Heide, M. and Våland, T. (2005), "Corporate social responsiveness: Exploring the dynamics of dad episodes", European Management Journal, Vol. 23 No. 5, pp. 495-506.

Higgins, C. and Walker, R. (2012), "Ethos, logos, pathos: Strategies of persuasion in social/environmental reports", Accounting Forum, Vol. 36 No. 3, pp. 194-208.

Holder-Webb, L., Cohen, J.R., Nath, L. and Wood, D. (2009), "The supply of corporate social responsibility disclosures among U.S. Firms", Journal of Business Ethics, Vol. 84 No. 4, pp. 497-527.

Holsti, O.R. (1969), Content Analysis for the Social Sciences and Humanities, Reading, MA: Addison-Wesley.

Hooghiemstra, R. (2000), "Corporate communication and impression management: New perspectives why companies engage in corporate social reporting", Journal of Business Ethics, Vol. 27 No.1, pp. 55-68.

Hotten, R. (2015), "Volkswagen: The scandal explained-BBC News", available at: http://www. bbc.co.uk/news/business-34324772 (accessed 19 April 2018).

Hotten, R. (2015), Volkswagen: The scandal explained. BBC News, 10, available at: https://www.bbc.co.uk/news/business-34324772 (accessed 19 July 2017).

Hyndman, N. and Liguori, M. (2016), "Justifying accounting change through global discourses and legitimation strategies. The case of the UK central government", Accounting and Business Research, Vol. 46 No. 4, pp.390-421.

Idowu, S.O., Vertigans, S. and Burlea, A.S. (2017), Corporate Social Responsibility in Times of Crisis: Practices and Cases from Europe, Africa and the World, 1st ed., Springer, Switzerland.

Islam, M.A., Dissanayake, T., Dellaportas, S. and Haque, S. (2016), "Anti-bribery disclosures: A response to networked governance", Accounting Forum, Vol. 42 No. 1, pp. 316.

Janney, J.J. and Gove, S. (2011), "Reputation and corporate social responsibility Aberrations, trends, and hypocrisy: Reactions to firm choices in the stock option backdating scandal", Journal of Management Studies, Vol. 48 No.7, pp.1562-1585.

Janssen, C., Sen, S. and Bhattacharya, C.B. (2015), "Corporate crises in the age of corporate social responsibility”, Business Horizons, Vol. 58 No. 2, pp.183-192.

Khan, A., Muttakin, M.B. and Siddiqui, J. (2013), "Corporate governance and corporate social responsibility disclosures: Evidence from an emerging economy", Journal of Business Ethics, Vol.114 No. 2, pp.207-223.

Krippendorff, K. (2004), Content Analysis: An Introduction to its Methodology, Thousand Oaks: Sage Publications.

Laufer, W. S. (2006), 'Illusions of compliance and governance', Corporate Governance: The International Journal of Business in Society, 6(3), pp. 239-249.

Lemon, A.J. and Cahan, S.F. (1997), "Environmental legislation and environmental disclosures: Some evidence from New Zealand", Asian Review of Accounting, Vol. 5 No. 1, pp. 78-105. 
Lepore, L., Pisano, S., Di Vaio, A. and Alvino, F. (2018), 'The myth of the "good governance code": an analysis of the relationship between ownership structure and the comply-or-explain disclosure', Corporate Governance: The International Journal of Business in Society. https://doi.org/10.1108/CG-08-2017-0197

Lewis, H., Dwyer, P., Hodkinson, S. and Waite, L. (2015), Precarious lives: Forced labour, exploitation and asylum, Policy Press, University of Bristol, Bristol.

Li, D., Huang, M., Ren, S., Chen, X. and Ning, L. (2016), "Environmental legitimacy, green innovation, and corporate carbon disclosure: Evidence from CDP China 100", Journal of Business Ethics, Vol. 150 No. 4, pp.1-16.

Lim, S. and McKinnon, J. (1993), "Voluntary disclosure by NSW statutory authorities: The influence of political visibility", Journal of Accounting and Public Policy, Vol. 12 No.3, pp.189-216.

Lin-Hi, N. and Blumberg, I. (2011), 'The relationship between corporate governance, global governance, and sustainable profits: Lessons learned from BP', Corporate Governance: The International Journal of Business in Society, Vol. 11 No. 5, pp.571-584.

Lundholm, R. and Van Winkle, M. (2006), "Motives for disclosure and non-disclosure: a framework and review of the evidence", Accounting and Business Research, Vol.36 No.1, pp.43-48.

Martínez-Ferrero, J., Ruiz-Cano, D. and García-Sánchez, I. (2016), “The causal link between sustainable disclosure and information asymmetry: The moderating role of the stakeholder protection context: CSR reporting and information asymmetry", Corporate Social Responsibility and Environmental Management, Vol. 23 No.5, pp. 319-332.

Mata, É., Kalagasidis, A.S. and Johnsson, F. (2013), "Energy usage and technical potential for energy saving measures in the Swedish residential building stock" Energy Policy, Vol. 55, pp.404-414.

Matsumura, E.M., Prakash, R. and Vera-Muñoz, S.C. (2013), "Firm-value effects of carbon emissions and carbon disclosures", The Accounting Review, Vol. 89 No. 2, pp.695-724.

Milne, M.J. (2002), "Positive accounting theory, political costs and social disclosure analyses: a critical look", Critical Perspectives on Accounting, Vol.13 No. 3, pp. 369-395.

Milne, M.J., Tregidga, H. and Walton, S. (2009), "Words not actions! The ideological role of sustainable development reporting" Accounting, Auditing \& Accountability Journal, Vol. 22 No. 8, pp.1211-1257.

Mitra, S. and Datta, P.P. (2014), “Adoption of green supply chain management practices and their impact on performance: an exploratory study of Indian manufacturing firms", International Journal of Production Research, Vol. 52 No. 7, pp.2085-2107.

Morsing, M. and Schultz, M. (2006), "Corporate social responsibility communication: stakeholder information, response and involvement strategies”, Business Ethics, A European Review, Vol. 15 No. 4, pp. 323-338.

Nakpodia, F., Adegbite, E., Amaeshi, K. and Owolabi, A., (2016) "Neither principles nor rules: Making corporate governance work in Sub-Saharan Africa", Journal of Business Ethics, Vol. 151 No.2, pp. 391-408. 
Nerantzidis, M. and Tsamis, A. (2017), 'Going back to go forward: on studying the determinants of corporate governance disclosure', Corporate Governance: The International Journal of Business in Society, 17(3), pp. 365-402.

Ness, K.E. and Mirza, A.M. (1991), "Corporate social disclosure: A note on a test of agency theory”, The British Accounting Review, Vol. 23 No.3, pp. 211-217.

Nestlé. (2012), "Nestlé in Society: Creating Shared Value and Meeting Our Commitments 2012", available at: http://www.nestle.com/assetlibrary/Documents/Library/Documents/Corporate_Social_Respo

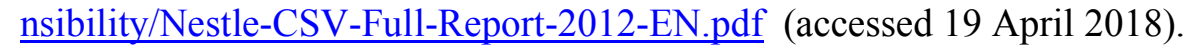

Neu, D., Warsame, H. and Pedwell, K. (1998), "Managing public impressions: environmental disclosures in annual reports", Accounting, Organizations and Society, Vol. 23 No. 3, pp. 265-282.

Nisiforou, O.A., Poullis, S. and Charalambides, A.G. (2012), "Behaviour, attitudes and Opinion of large enterprise employees with regard to their energy usage habits and adoption of energy saving measures", Energy and Buildings, Vol. 55, pp.299-311.

O'Donovan, G. (2002), "Environmental disclosures in the annual report: Extending the applicability and predictive power of legitimacy theory", Accounting, Auditing \& Accountability Journal, Vol. 15 No. 3, pp. 344-371.

Othman, Z. and Rahman, R.A. (2014), “Attributes of ethical leadership in leading good governance" International Journal of Business and Society, Vol. 15 No. 2, pp.359.

Panchapakesan, S. and McKinnon, J. (1992), "Proxies for political visibility: a preliminary examination of the relation among some potential proxies", Accounting Research Journal, Vol. 5 No. 1, pp. 71-80.

Petra, S. T. (2006), 'Corporate governance reforms: Fact or fiction?', Corporate Governance: The International Journal of Business in Society, 6(2), pp. 107-115.

Pollach, I. (2015), "Strategic corporate social responsibility: the struggle for legitimacy and reputation", International Journal of Business Governance and Ethics, Vol. 10 No. 1, pp.5775.

Pombo, O., Allacker, K., Rivela, B. and Neila, J. (2016), "Sustainability assessment of Energy saving measures: A multi-criteria approach for residential buildings retrofitting - A case study of the Spanish housing stock" Energy and Buildings, Vol. 116, pp.384-394.

Reimsbach, D. and Hahn, R. (2015), “The effects of negative incidents in sustainability reporting on investors' judgments-An experimental study of third $\square$ party versus selfdisclosure in the realm of sustainable development", Business Strategy and the Environment, Vol. 24 No. 4, pp. 217-235.

Saunders, M.N.K., Lewis, P. and Thornhill, A. (2015), Research Methods for Business Students, Pearson Education, Essex, UK.

Song, Y., Wang, H. and Zhu, M. (2018), "Sustainable strategy for corporate governance based on the sentiment analysis of financial reports with CSR", Financial Innovation, Vol. 4 No. 1, pp.2. 
Stake, R.E. (2005), "Qualitative case studies. In N.K. Denzin and Y.S. Lincoln (Eds.) The Sage Handbook of Qualitative Research (3rd edition), Sage Publications, London, pp. 443465.

Stanton, P. and Stanton, J. (2002), "Corporate annual reports: Research perspectives used", Accounting, Auditing \& Accountability Journal, Vol. 15 No.4, pp.478-500.

Steenkamp, N. and Northcott, D. (2007), "Content analysis in accounting research: The practical challenges", Australian Accounting Review, Vol. 17 No. 43, pp.12-25.

Suchman, M.C. (1995), "Managing legitimacy: Strategic and institutional approaches", The Academy of Management Review, Vol. 20 No.3, pp.571-610.

Talbot, D. and Boiral, O. (2015), "Strategies for climate change and impression management: A case study among Canada's large industrial emitters" Journal of Business Ethics, Vol. 132 No.2, pp.329-346.

Ullah, S., Ahmad, S., Akbar, S. and Kodwani, D. (2018), "International evidence on the determinants of organizational ethical vulnerability". British Journal of Management. https://doi.org/10.1111/1467-8551.12289

Van Staden, C.J. and Hooks, J. (2007), "A comprehensive comparison of corporate environmental reporting and responsiveness", British Accounting Review, Vol. 39 No. 3, pp.197-210.

Watts, R.L. and Zimmerman, J.L. (1978), "Towards a positive theory of the determination of accounting standards", The Accounting Review, Vol. 53 No. (1), pp. 112-134.

Yuthas, K., Rogers, R. and Dillard, J.F. (2002), "Communicative Action and Corporate Annual Reports", Journal of Business Ethics, Vol. 41 No. 1, pp.141-157.

Zeng, S.X., Xu, X.D., Yin, H.T. and Tam, C.M. (2012), "Factors that drive Chinese listed companies in voluntary disclosure of environmental information" Journal of Business Ethics, Vol. 109 No. 3, pp.309-321. 
Table 1: Definition of different categories (legitimation strategies)

\begin{tabular}{|c|c|}
\hline Legitimisation strategy & Description \\
\hline Marginalisation & $\begin{array}{l}\text { This relates to the voluntary disclosure suggesting that the negative incident or } \\
\text { scandal was irrelevant or unimportant. This would try to suggest that it was only } \\
\text { a minor or insignificant incident and should not be taken with such severity. }\end{array}$ \\
\hline Abstraction & $\begin{array}{l}\text { This relates to the generalisation of the incident, implying that it occurs } \\
\text { throughout the whole industry sector and not just within the company. This } \\
\text { suggests that the incident is not only the companies fault but is a typical industry } \\
\text { wide occurrence. }\end{array}$ \\
\hline Indicating Facts & $\begin{array}{l}\text { This is the mention of accurate figures relating to the incident, which quantifies } \\
\text { the existence of the negative incident. }\end{array}$ \\
\hline $\begin{array}{l}\text { Instrumental } \\
\text { rationalisation }\end{array}$ & $\begin{array}{l}\text { This mentions the positive aspects and outcomes of the incident to minimise its } \\
\text { negative effect. }\end{array}$ \\
\hline $\begin{array}{l}\text { Theoretical } \\
\text { rationalisation }\end{array}$ & $\begin{array}{l}\text { This relates to the emphasis of inevitability and that the incident is of natural } \\
\text { behaviour. }\end{array}$ \\
\hline Authorisation & $\begin{array}{l}\text { This emphasises the support of authorities or benchmarks to compare or } \\
\text { legitimise their actions towards the incident. }\end{array}$ \\
\hline $\begin{array}{l}\text { Corrective action type } \\
1\end{array}$ & $\begin{array}{l}\text { This is the acknowledgement of the negative incident and the imprecise } \\
\text { measures they carry out, through ideas, intent or the solution to rectify the } \\
\text { incident. }\end{array}$ \\
\hline $\begin{array}{l}\text { Corrective action type } \\
2\end{array}$ & $\begin{array}{l}\text { This is the acknowledgement of the negative incident with exact and precise } \\
\text { measures of correcting the incident. This gives no ambiguity with exact details of } \\
\text { the event. }\end{array}$ \\
\hline
\end{tabular}


Table 2: Keywords applied in the content analysis

\begin{tabular}{ll}
\hline Generic Keywords & Specific Keywords \\
\hline Incident & Underage \\
Accident & Loss \\
Harm & Launder \\
Risk & Spill \\
Conflict & Deepwater horizon \\
Negative & Privacy \\
Human rights & Battery \\
Environment & Reserve \\
Scandal & Overstate \\
Corruption & Restatement \\
Bribery & Employees \\
Tax (Avoidance) & Deforestation \\
Child labour (Labour) & Animals \\
Discrimination & Wildlife \\
Issue & \\
Accountable & \\
Action & \\
Response & \\
Failure & \\
\hline
\end{tabular}


Table 3: Types of controversies

\begin{tabular}{|c|c|c|c|}
\hline Company Name & Industry & Year of Incident & Incident \\
\hline Amazon & Online Retailing & 2014 & Tax Avoidance \\
\hline Apple & Technology & 2010 & Child Labour \\
\hline BHP Billiton & Mining & 2015 & $\begin{array}{l}\text { Dam collapsed \& indigenous } \\
\text { community displaced }\end{array}$ \\
\hline $\mathrm{BP}$ & Oil and gas & 2010 & Oil Spill \\
\hline GSK & Pharmaceutical & 2014 & Corruption in China \\
\hline \multirow[t]{2}{*}{$\mathrm{H} \& \mathrm{M}$} & Clothing retailer & 2010 & Factory Fire \\
\hline & & & Child labour \\
\hline HSBC & Bank & 2013 & Money Laundering \\
\hline Nestlé & Food & 2012 & Child Labour \\
\hline & & & Deforestation for Palm Oil \\
\hline Nokia & Technology & 2009 & $\begin{array}{l}\text { Selling Spying Equipment to } \\
\text { Iran (violation of UN } \\
\text { Resolution) }\end{array}$ \\
\hline Npower & Energy & 2013 & Tax Avoidance \\
\hline Olympus & Electronics & 2011 & Fraud \\
\hline Samsung & Technology & 2016 & $\begin{array}{l}\text { Battery Burnout on Samsung } \\
\text { Galaxy Note } 7 \text { Phones }\end{array}$ \\
\hline Shell & Oil and Gas & 2004 & Fraud - Overstated Reserves \\
\hline Siemens & $\begin{array}{l}\text { Engineering and } \\
\text { manufacturing }\end{array}$ & 2008 & Corruption \\
\hline Sports Direct & Sports retailer & 2015 & Human Rights in the Workplace \\
\hline Tesco & $\begin{array}{l}\text { Grocery and } \\
\text { retailer }\end{array}$ & 2015 & Overstated Profits \\
\hline Toshiba & Technology & 2015 & Overstate Operating Profits \\
\hline Volkswagen & Automobiles & 2015 & Emissions rigging scandal \\
\hline Zara & Clothing Retailer & 2013 & Child Labour \\
\hline
\end{tabular}


Table 4: Coding Scheme

\begin{tabular}{|c|c|c|c|c|}
\hline $\mathrm{H} \& \mathrm{M}$ & Social & 2010 & $\begin{array}{l}\text { "Today, incidents of children working in our first-tier supply chain } \\
\text { occur rarely" (H\&M, 2010: 103) }\end{array}$ & Marginalisation \\
\hline Npower & Accounting & 2012 & $\begin{array}{l}\text { "Taxation is a complex part of any business's operation" (RWE } \\
\text { Npower, 2013: 12) }\end{array}$ & Abstraction \\
\hline GSK & Accounting & 2014 & $\begin{array}{l}\text { "We are exposed to bribery and corruption risk through our global } \\
\text { business operations." (GSK, 2014: 43) }\end{array}$ & Theoretical rationalisation \\
\hline Tesco & Accounting & 2015 & $\begin{array}{l}\text { "This is now the subject of an investigation by the Serious Fraud } \\
\text { Office and civil proceedings in the United States." (Tesco PLC, } \\
\text { 2015: 12) }\end{array}$ & Authorisation \\
\hline Siemens & Accounting & 2008 & $\begin{array}{l}\text { "Since 2007, we have trained well over 200,000 employees in } \\
\text { compliance matters." (Siemens, 2008: 65) }\end{array}$ & Corrective action type 2 \\
\hline
\end{tabular}


Table 5: Summary of legitimation strategies for all scandals

\begin{tabular}{lccc}
\hline Strategy & Accounting & Social & Environmental \\
\hline Number of Marginalisation occurrences & 2 & 1 & 2 \\
Abstraction & 6 & 0 & 3 \\
Indicating facts & 21 & 5 & 15 \\
Instrumental rationalisation & 0 & 0 & 0 \\
Theoretical rationalisation & 2 & 2 & 0 \\
Authorisation & 6 & 1 & 12 \\
Corrective action type 1 & 23 & 10 & 25 \\
Corrective action type 2 & & & \\
\end{tabular}

